\title{
Pengaruh Efikasi Diri terhadap Hasil Belajar Matematika pada Siswa Kelas IV SD Segugus Rujakbeling Kecamatan Kebumen Kabupaten Kebumen Tahun Ajaran 2018/2019
}

\author{
Febriana Setyowati ${ }^{1}$, Wahyudi ${ }^{2}$, Rokhmaniyah ${ }^{3}$ \\ 1,2,3 Universitas Sebelas Maret \\ Febrianasetyowati9@gmail.com
}

\section{Article History}

accepted 01/06/2019

\begin{abstract}
This study aimed to prove the presence or absence of a positive effect of self-efficacy on the mathematics learning outcomes of grade IV students of public elementary schools in Rujakbeling in Academic Year 2018/2019 and the amount of self-efficacy contributions of grade 4 students of elementary school students in Rujakbeling in Academic Year 2018/2019. This research is a quantitative research with espost-facto method. Sampling was calculated using the Slovin formula and taken randomly with a proportionalate stratified random sampling technique. In data analysis, researchers used the PASW version 18. The results of this study indicated the following regression equation $Y=-3.054+0.185 X$ which was statistically significant with tcount $=4.251>t_{\text {table }}=1.982$ with a contribution of $14.3 \%$. Based on the analysis and discussion, it can be concluded that there was a positive and significant influence between self-efficacy and mathematics learning outcomes of fourth grade students in SD se-Gugus Rujakbeling.
\end{abstract}

Keywords: self efficacy, learning outcomes, mathematics

\begin{abstract}
Abstrak
Penelitian ini bertujuan untuk membuktikan ada tidaknya pengaruh positif efikasi diri terhadap hasil belajar matematika siswa kelas IV SD se-Gugus Rujakbeling tahun ajaran 2018/2019 dan besarnya sumbangan efikasi diri siswa kelas IV SD se-Gugus Rujakbeling tahun ajaran 2018/2019. Penelitian ini merupakan penelitian kuantitatif dengan metode espost-facto. Pengambilan sampel dihitung menggunakan rumus Slovin dan diambil secara acak dengan teknik sampel Proporsionate Stratified random Sampling. Pada analisis data, peneliti menggunakan aplikasi PASW versi 18. Hasil penelitian ini menghasilkan persamaan regresi sebagai berikut $Y=-3,054+0,185 \mathrm{X}$ yang signifikan secara statistik dengan thitung $=4.251>t_{\text {tabel }}$ $=1,982$ dengan sumbangan sebesar $14,3 \%$. Berdasarkan analisis dan pembahasan dapat disimpulkan bahwa terdapat pengaruh positif dan signifikan antara efikasi diri dan hasil belajar matematika siswa kelas IV SD se-Gugus Rujakbeling.
\end{abstract}

Kata kunci: efikasi diri, hasil belajar, matematika 


\section{PENDAHULUAN}

Pendidikan merupakan suatu kegiatan terencana yang dikakukan secara sengaja dan berkesinambungan guna mengembangkan sikap, pengetahuan dan keterampilan yang berguna untuk membekali siswa dalam mempersiapkan dirinya di masa mendatang. Menurut Paling (Widyaninggar, 2015: 92) matematika adalah suatu suatu ilmu universal yang mendasari perkembangan teknologi modern, memiliki peranan penting dalam berbagai disiplin ilmu serta memajukan daya pikir manusia. Selain itu Hendriana (2013: 13) juga mengungkapkan bahwa matematika memiliki peranan yang penting dalam pembentukan pola pikir yang logis pada kehidupan sehari-hari. Namun, pentingnya peranan matematika ini tidak sejalan dengan kenyataan yang ada. Sebagian siswa masih merasa bahwa matematika adalah salah satu mata pelajaran yang sulit. Seperti halnya yang diungkapkan oleh Pakar Matematika dari Departemen IImu Komputer dan Elektronika Fakultas MIPA UGM yang menyatakan bahwa matematika merupakan pembelajaran yang penting, akan tetapi tidak disukai oleh siswa karena isi matematika yang abstrak (Mawardi, 2017: 24). Ketidaksukaan siswa terhadap matematika mengakibatkan munculnya permasalahan baru dalam pemecahan permasalahan pada soal matematika, data dari Trends in Intenational Mathematics and Science Study (TIMSS) 2015 Indonesia menempati ranking 44 dari 49 negara, hal ini menunjukkan masih rendahnya kemampuan pemecahan masalah pada soal matematika. Selain itu siswa kelas 4 masih memiliki rasa percaya diri yang rendah, diketahui pada tahun 2015 siswa yang percaya diri terhadap kemampuannya hanya $13 \%$ saja (TIMSS, 2015).

Saat ini hasil belajar masih dianggap sebagai penentu kecerdasan anak. "Learning outcomes outline is an important indicator for educators in evaluating curriculum design" yang berarti bahwa hasil belajar merupakan suatu indikator penting bagi pengajar untuk mengevaluasi desain kurikulum yang telah digunakan (Wang, 2015:25). Sihaloho, Rahayu dan Wibowo (2018: 64) mengungkapkan bahwa hasil belajar merupakan hasil yang diperoleh siswa setelah mengalami kegiatan belajar mengajar yang terdiri dari kognitif, afektif dan psikomotor.

Terdapat 2 faktor yang mempengaruhi keberhasilan siswa dalam evaluasi hasil belajar baik faktor dari dalam diri siswa maupun faktor dari luar diri siswa. Salah satu faktor dari dalam diri individu adalah efikasi diri. Efikasi Diri merupakan salah satu faktor yang mampu mempengaruhi tindakan dan keberhasilan individu untuk mencapai prestasi belajar yang memuaskan. Brown dan Inouye (Bandura, 1997: 195). Feist, J.Feist, dan Roberts (2018: 157) menyatakan bahwa efikasi diri merupakan keyakinan yang ada dalam diri seseorang terhadap kemampuannya untuk melakukan suatu perilaku. Bandura (1997: 83) menyatakan bahwa "self-efficacy as personal judgments of one's capabilities to organize and excute courses of action to attain designated goals, and strength across activities and contexts". Bandura mendefinisikan efikasi diri sebagai penilaian terhadap kemampuan seseorang untuk mengatur dan melaksanakan tindakan untuk mencapai tujuan yang telah ditetapkan, dan berusaha untuk menilai tingkat, keumuman dan kekuatannya pada seluruh kegiatan dan konteks. Selain itu, Bandura juga mengatakan bahwa efikasi diri pada dasarnya merupakan hasil proses berfikir yang berupa keputusan, keyakinan atau pengharapan mengenai sejauh mana individu tersebut memperkirakan kemampuan-nya dalam melaksanakan suatu tindakan atau tugas yang diperlukan untuk mencapai hasil yang diharapkan. Sedangkan menurut Ghufron dan Suminta (2012: 73) efikasi diri merupakan suatu hal yang terdapat pada diri seseorang yang dapat mempengaruhi tindakan yang akan dilakukan dalam mencapai tujuan.

Kesadaran mengenai efikasi diri perlu ditingkatkan terutama pada mata pelajaran matematika yang selama ini masih dianggap sulit karena matematika memiliki kaitan yang erat di kehidupan sehari-hari. Hal-hal yang abstrak cenderung membuat siswa sulit untuk menangkap dan memahami suatu konsep atau materi sehingga 
kepercayaan siswa dalam mengatasi tantangan berupa permasalahan atau soal menjadi rendah. Menurut Bandura (Feist, J.Feist, \& Roberts, 2018: 158-160) efikasi diri dapat diperoleh, ditingkatkan bahkan dikurangi melalui salah satu atau kombinasi dari beberapa sumber sehingga dapat mengubah persepsi mengenai efikasi dirinya.

Tujuan tujuan dari penelitian ini adalah: (1) membuktikan pengaruh positif efikasi diri terhadap hasil belajar matematika siswa kelas IV SD se-Gugus Rujakbeling tahun ajaran 2018/2019, (2) mengetahui besarnya sumbangan efikasi diri siswa kelas IV SD se-Gugus Rujakbeling tahun ajaran 2018/2019.

\section{METODE}

Penelitian ini merupakan penelitian kuantitatif dengan metode expost-facto. Variabel pada penelitian ini terdiri dari variabel bebas $(X)$ yaitu variabel efikasi diri dan variabel terikat $(\mathrm{Y})$ yaitu variabel hasil belajar matematika.

Populasi dari penelitian ini adalah seluruh siswa kelas IV SD Se-Gugus Rujakbeling Kecamatan Kebumen Kabupaten Kebumen Tahun Ajaran 2018/2019 sejumlah 151 siswa. Secara keseluruhan jumlah sekolah di Gugus Rujakbeling ada 5 SD yaitu SDN 1 Kebumen, SDN 2 Kebumen, SDN 5 Kebumen, SDN 7 Kebumen dan SD Kristen Penabur.

Sampel dihitung menggunakan rumus Slovin sehingga didapatkan jumlah sampel dari penelitian ini yaitu 110 siswa. Teknik pengambilan sampel atau teknik sampling yang digunakan dalam penelitian ini adalah sampel acak proporsional (Proporsionate Stratified random Sampling).

Teknik yang digunakan dalam mengumpulkan data adalah dengan angket dan tes. Angket digunakan untuk mengumpulkan data penelitian pada variabel bebas dan tes digunakan untuk memgumpulkan data pada variabel terikat.

Uji validitas pada penelitian ini menggunakan analisis korelasi Product Moment Pearson dan pada uji reliabilitas digunakan rumus Cronbach Alpha.

Uji prasyarat data penelitian ini yaitu uji normalitas data, uji linieritas data. Setelah data memenuhi prasyarat yang ditentukan, data dianalisis menggunakan regresi linier sederhana.

\section{HASIL DAN PEMBAHASAN}

Penelitian ini dilakukan dengan memberikan angket efikasi diri dan soal tes matematika pada siswa kelas IV SD. Analisis parametris meliputi uji normalitas dan uji linieritas menggunakan aplikasi PASW versi 18. Uji normalitas menggunakan metode uji normalitas kolmogrov-smirnov yang menunjukkan nilai $\alpha=0,200$ pada variabel $X$ maupun variabel $Y$ dengan nilai signifikansi $>0,05$ sehingga kedua variabel tersebut berdistribusi normal. Uji linieritas menunjukkan nilai Sig Deviation from Linearity sebesar 0,107. Nilai Sig. Deviataion from Linearity menunjukkan > nilai Sig. $(0,05)$. Hal ini menunjukkan bahwa hasil belajar matematika dan efikasi diri siswa memiliki hubungan linier.

Pengujian hipotesis menggunakan aplikasi PASW versi 18 didapat nilai $\mathrm{f}_{\text {hitung }}$ sebesar 18.069 dan nilai $f_{\text {tabel }}$ sebesar 3,93 dengan df1 = 1 dan df $2=108$ ( $\mathrm{n}-\mathrm{k}$ atau $110-2=109$ ) dengan tingkat signifikansi atau probabilitas 0,000 yang berarti model regresi pada penelitian ini dapat dipakai untuk memprediksi tingkat efikasi diri siswa.

Hasil uji signifikansi menggunakan uji t untuk mengetahui pengaruh signifikan tingkat efikasi diri. Diketahui $t_{\text {hitung }}$ sebesar 4.251 dan nilai $t_{\text {tabel }}$ sebesar 1,982 dengan taraf signifikansi 0,05 . Nilai thitung $(4.251)>t_{\text {tabel }}(1,982)$ sehingga $\mathrm{HO}$ ditolak. Hal ini menunjukkan bahwa terdapat pengaruh antara efikasi diri dengan hasil belajar matematika. Hal tersebut menandakan bahwa peningkatan dan penurunan hasil belajar siswa dipengaruhi oleh efikasi diri. 
Untuk persamaan regresi linier sederhana dapat dilihat pada tabel 4.8. diketahui bahwa konstanta (a) adalah -3,054. Sedangkan nilai koefisien (b) dari tingkat efikasi diri adalah 0,185 . Sehingga persamaan regresi linier sederhananya dapat ditulis:

$Y=-3,054+0,185 X$

Dari persamaan di atas dapat diketahui bahwa nilai konstanta sebesar -3,054 artinya jika efikasi diri siswa $(X)$ nilainya adalah nol (0) maka hasil belajar matematika (Y) nilainya negatif yaitu sebesar $-3,054$. Koefisien regresi tingkat efikasi diri bertambah sebesar 0,185 . Tanda positif pada persamaan regresi tersebut menunjukkan pengaruh positif antara variabel hasil belajar matematika dan efikasi diri artinya jika semakin tinggi efikasi diri siswa maka semakin tinggi hasil belajarnya.

Hasil penelitian ini sejalan dengan penelitian yang telah dilakukan oleh Sihaloho, Rahayu dan Wibowo (2018: 62) yang menyatakan bahwa efikasi diri berpengaruh positif dan signifikan terhadap hasil belajar. Selain itu hasil penelitian ini juga sesuai dengan hasil penelitian dari Sudjiono (2014: 131) yang menyatakan bahwa efikasi diri berpengaruh signifikan terhadap hasil belajar matematika.

Selain itu penelitian ini juga diperkuat oleh hasil penelitian dari Hsieh dan HyunSook (2010: 606) yang mengungkapkan bahwa peserta didik dengan tingkat efikasi diri yang tinggi mendapat skor hasil tes lebih banyak dibandingkan dengan peserta didik yang memiliki tngkat efikasi diri yang rendah.

Dengan demikian, keberhasilan siswa dalam mendapatkan hasil belajar yang baik dapat dilihat dari tingkat efikasi dirinya. Semakin tinggi tingkat efikasi diri siswa maka semakin tinggi dorongan belajar bagi dirinya dalam belajar sehingga mendapatkan hasil belajar yang maksimal.

Sumbangan efikasi diri terhadap hasil belajar matematika dapat dicari menggunakan rumus yang dikemukakan oleh Winarsunu (2007: 203-204). Berdasarkan perhitungan sumbangan efektif pada variabel efikasi diri dan hasil belajar matematika diperoleh hasil sebesar 14,3\%. Hal ini menunjukkan bahwa efikasi diri berpengaruh positif terhadap hasil belajar matematika siswa dan sisanya dipengaruhi oleh faktor lain yang tidak diteliti dalam penelitian ini. Hal ini sesuai dengan pendapat Widyaninggar (2015: 90) yang menyatakan bahwa efikasi diri bukanlah satu-satunya faktor internal yang dapat mempengaruhi hasil belajar siswa. Akan tetapi terdapat faktor-faktor lain seperti kedisiplinan, motivasi, minat, bakat, kreatifitas, dan locus of control yang dapat mempengaruhi tinggi rendahnya hasil belajar siswa dari faktor internal. selain itu Slameto (Lindaningtyas, Witurachmi dan Hamidi, 2017: 191) juga menyebutkan bahwa terdapat faktor internal dan faktor eksternal yang mempengaruhi hasil belajar siswa. Faktor internal yang meliputi faktor jasmani, psikologi dan kelelahan, sedangkan faktor eksternal mencakup lingkungan sekitar baik keluarga, masyarakat dan lingkungan.

\section{SIMPULAN}

Berdasarkan hasil penelitian mengenai efikasi diri dan hasil belajar matematika siswa kelas IV SD se-Gugus Rujakbeling tahun ajaran 2018/2019 dapat ditarik kesimpulan sebagai berikut:

1. Efikasi diri berpengaruh secara positif dan signifikan terhadap hasil belajar matematika siswa kelas IV se-Gugus Rujakbeling dengan model persamaan regresi $Y=-3,054+0,185 X$ yang signifikan secara statistik dengan thitung $=4.251>$ $t_{\text {tabel }}=1,982$.

2. Efikasi diri memberikan sumbangan sebesar $14,3 \%$ terhadap hasil belajar matematika siswa kelas IV SD, sedangkan sisanya sebesar $85,7 \%$ dipengaruhi oleh variabel lain yang tidak dibahas dalam penelitian ini yaitu minat, bakat, kreatifitas, kedisiplinan, motivasi dan locus of control. 


\section{DAFTAR PUSTAKA}

Bandura, A. (1997). Self-Efficacy: The Exercise of Control. New York : W. H. Freeman and Company.

Feist, J., Feist, G.J., \& Roberts,T. (2018). Teori Kepribadian Theories of Personality. Jakarta : Salemba Humanika.

Ghufron, M.N., \& Suminta R.R. (2012). Teori-teori Psikologi. Yogyakarta : Ar-Ruzz Media.

Hendriana, H. (2013). Membangun Kepercayaan Diri Siswa Melalui Pembelajaran Matematika Humanis. Prosiding Seminar Nasional Matematika dan Pendidikan Matematika. Volume 1.

Hsieh, P.P.H., \& Hyun-Sook, K. (2010). Attribution and self-efficacy and their interrelationship in the Korean EFL context. Language Learning, 60(3), 606627.

Lindaningtyas, Witurachmi, S., \& Hamidi, N. (2017). Pengaruh Efikasi Diri dan Perilaku Belajar Terhadap Prestasi Belajar Siswa SMK di Karanganyar. Tata Arta: Jurnal Pendidikan Akuntansi, 3(1).

Mawardi, B. (2017, 14 November). Matematika, Penting Tetapi Tidak Disukai. Suara Merdeka. hlm 24.

Sihaloho, L., Rahayu, A., \& Wibowo, L.A. (2018). Pengaruh Efikasi Diri (Self Efficacy) terhadap Hasil Belajar Ekonomi Siswa Kelas XI IPS SMA Negeri Se-Kota Bandung. JINoP (Jurnal Inovasi Pembelajaran), 4(1), 62-70.

Sudjiono. (2014). Pengaruh Mind Maping terhadap Peningkatan Efikasi Diri Matematika dan Prestasi Belajar Matematika Siswa SMP. Disertasi Tidak Dipublikasikan. Universitas Gajah Mada, Yogyakarta.

TIMSS. (2015). International Mathematics Achievement East Asian Countries Top Achievers at Fourth Grade in Mathematics.

Wang, S.T., \& Chen, C.C. (2015). Path Analysis on the Factors Influencing Learning Outcome for Hospitality Interns-From the Flow Theory Perspective. Journal of Education and Learning, 4(3), 25.

Widyaninggar, A.A. (2015). Pengaruh efikasi diri dan lokus kendali (locus of control) terhadap prestasi belajar Matematika. Formatif: Jurnal IImiah Pendidikan MIPA, 4(2).

Winarsunu, T. (2007). Statistik dalam Penelitian Psikologi dan Pendidikan. Malang : UMM Press. 